\title{
ANALISIS FAKTOR EKSTERNAL YANG DOMINAN TERHADAP BIAYA OVERHEAD PROYEK KONSTRUKSI
}

\author{
Hendi Wijaya' ${ }^{1}$ dan Basuki Anondho² \\ ${ }^{1}$ Program Studi Sarjana Teknik Sipil, Universitas Tarumanagara, Jl. Letjen S. Parman No.1 Jakarta \\ hendi.325160103@stu.untar.ac.id \\ ${ }^{2}$ Program Studi Sarjana Teknik Sipil, Universitas Tarumanagara, Jl. Letjen S. Parman No.1 Jakarta \\ basukia@ft.untar.ac.id
}

Masuk: 12-07-2021, revisi: 07-08-2021, diterima untuk diterbitkan: 19-08-2021

\begin{abstract}
Overhead costs are one of the cost components that play an important role in the performance of construction companies in maintaining good quality work. However, the overhead costs in a project vary and are influenced by several factors. One of the factors that influence it is the external factor of the project. The external factors of each project are different. This is because each project must adapt the workplace environment to certain functions, designs, and preferences. On that basis, to be able to better estimate overhead costs in a project, it is necessary to further identify what external factors dominantly affect construction project overhead costs, and set aside a few percent of the direct costs of construction projects to anticipate risks caused by construction projects. by overhead costs. Data was collected through a structured questionnaire distributed to several people working in the construction sector from contractors in several regions in Indonesia. From the results of the analysis, there are 3 groups of external factors that dominantly affect construction project overhead costs, namely economic factors, legal factors, and sociocultural factors related to the COVID-19 pandemic.
\end{abstract}

Keywords: Overhead Cost, External Factors, construction project

\section{ABSTRAK}

Biaya overhead merupakan salah satu komponen biaya yang berperan dan berpengaruh penting terhadap kinerja perusahaan konstruksi dalam menjaga kualitas pekerjaan yang baik. Akan tetapi biaya overhead dalam suatu proyek berbeda-beda, dan dipengaruhi oleh beberapa faktor. Salah satu faktor yang mempengaruhinya ialah faktor eksternal proyek. Faktor eksternal dari setiap proyek berbeda-beda. Hal ini dikarenakan setiap proyek harus menyesuaikan lingkungan tempat kerja dengan fungsi, desain, serta prefensi tertentu. Atas dasar itu, untuk dapat lebih baik dalam mengestimasi biaya overhead dalam sebuah proyek maka diperlukan identifikasi lebih jauh terhadap faktor-faktor eksternal apa saja yang dominan berpengaruh terhadap biaya overhead proyek konstruksi, dan menyisihkan beberapa persen dari biaya langsung proyek konstruksi untuk mengantisipasi resiko yang disebabkan oleh biaya overhead. Data dikumpulkan melalui kuesioner terstruktur yang disebarkan kepada sejumlah orang yang bekerja di bidang konstruksi dari pihak kontraktor beberapa wilayah di Indonesia. Dari hasil analisis diperoleh sebanyak 3 kelompok faktor eksternal yang dominan mempengaruhi biaya overhead proyek konstruksi, yaitu faktor ekonomi, faktor legal, dan faktor sosial-budaya yang berhubungan dengan adanya pandemi COVID-19.

Kata Kunci: Biaya Overhead, Faktor Eksternal, proyek konstruksi

\section{PENDAHULUAN}

Menurut Wattimury (2015), Pengendalian biaya dalam proyek konstruksi merupakan usaha yang dilakukan untuk mengendalikan penggunaan biaya dalam suatu proyek mulai dari awal sampai proyek selesai. Dalam hal mengestimasi biaya, salah satu parameter utama dalam memperkirakan harga dalam penawaran adalah biaya overhead.

Menurut El-Sawalhi \& El-Riyati (2015) dalam penelitiannya biaya overhead proyek mempunyai peran dan pengaruh yang signifikan terhadap kinerja perusahaan konstruksi dalam menjaga kualitas pekerjaan yang baik. Jadi atas dasar itu, biaya Overhead merupakan biaya yang tidak dapat di distribusikan secara langsung terhadap suatu produk atau jasa, dan komponen pekerjaan konstruksi, tetapi harus dikeluarkan oleh kontraktor untuk mendukung pekerjaan tersebut. 
Besarnya biaya overhead dalam suatu proyek bervariasi dan dipengaruhi oleh faktor eksternal pada proyek tersebut. Faktor eksternal pada setiap proyek tentunya berbeda-beda, karena pada umumnya proyek konstruksi memiliki penyesuaiannya masing-masing karena tidak ada proyek yang sama. Hal tersebut dikarenakan setiap proyek harus memiliki penyesuaian terhadap lingkungan tempat kerja dengan fungsi, desain, dan preferensi tertentu (Kiew, Ismail, \& Yusof, 2013)

Selain itu, biaya overhead juga memegang peranan penting dalam persaingan untuk memenangkan tender. Banyak kontraktor yang mengambil resiko dan tidak memperhitungkan biaya overhead yang sebenarnya. Akhirnya, hal tersebut mengakibatkan kontraktor tersebut rugi, dan bahkan gulung tikar (El-Sawalhi \& El-Riyati, 2015).

Oleh karena itu, diperlukan penelitian tentang faktor-faktor eksternal proyek apa saja yang dominan berpengaruh terhadap biaya overhead suatu proyek konstruksi agar nantinya kontraktor dapat mengantisipasi resiko yang disebabkan oleh faktor eksternal yang dominan berpengaruh terhadap biaya overhead, serta mengetahui kisaran berapa persen biaya overhead yang diambil oleh para kontraktor berdasarkan biaya langsung proyek konstruksi untuk mengantisipasi resiko yang disebabkan dari biaya overhead.

\section{Pengertian Proyek Konstruksi}

Soeharto (1999) mendefinisikan proyek sebagai kegiatan sementara yang berlangsung untuk waktu yang terbatas, dengan alokasi sumber daya tertentu, dan bertujuan untuk melakukan tugas-tugas yang tujuannya telah digariskan dengan jelas.

Menurut Mahendra (2004), proyek adalah kegiatan yang dilakukan dengan waktu dan sumber daya yang terbatas untuk mencapai hasil akhir yang telah ditentukan. Untuk mencapai hasil akhir, kegiatan proyek tunduk pada tiga kendala, yaitu biaya, waktu, dan mutu.

\section{Pengertian Faktor Eksternal}

Pada proyek konstruksi, faktor eksternal merupakan faktor yang asalnya dari luar proyek pembangunan, seperti lingkungan, sosial budaya, politik, hukum, dan alam. Dalam penelitian ini, membahas tentang faktor eksternal yang dominan berpengaruh terhadap biaya overhead.

\section{Pengertian Biaya Overhead}

Cilensek (1991) mendefinisikan biaya overhead dalam industri konstruksi adalah biaya-biaya yang bukan merupakan biaya sebenarnya dari proyek konstruksi, namun dibebankan kepada kontraktor untuk mendukung jalannya proyek. Lebih jauh, biaya overhead juga telah didefinisikan sebagai kasus yang menunjukkan biaya pekerjaan dan hampir dianggap sebagai biaya tetap yang harus dibayar oleh kontraktor.

Filicetti dalam Hesami et al. (2014) mendefinisikan biaya overhead sebagai biaya-biaya yang dikenakan selama bisnis tetapi tidak secara langsung dikaitkan dengan produk tertentu. Oleh karena itu, biaya overhead pada dasarnya adalah terlepas dari jenis dan produk proyek.

Hesami et al (2014) juga mengungkapkan bahwa meskipun biaya overhead bukan komponen yang utama dalam biaya, namun memiliki peranan penting bagi kontraktor dalam memenangkan persaingan. Sehingga kontraktor harus mempertimbangkan biaya overhead jika ingin memengangkan persaingan dalam satu penawaran. Oleh karena itu, biaya overhead sangat penting untuk estimasi biaya dan kurangnya akurasi estimasi tersebut dapat menyebabkan perusahaan mengalami kerugian kompetitif.

\section{Identifikasi awal faktor eksternal dalam biaya overhead}

Dalam penelitian ini beberapa referensi seperti jurnal dan buku digunakan untuk mengetahui sejumlah faktor eksternal yang mempengaruhi biaya overhead. Hasil tabulasi identifikasi awal dapat dilihat pada Tabel 1 berikut.

Tabel 1 Tabulasi Identifikasi awal faktor-faktor eksternal yang berpengaruh terhadap biaya overhead

\begin{tabular}{lllc}
\hline & \multicolumn{1}{c}{ Refrensi } & \multicolumn{1}{c}{ Indikator } & Dimensi \\
\hline \multirow{2}{*}{1} & $\begin{array}{l}\text { Jaafari, Ali, (2001), Management of risks, uncertainties } \\
\text { and opportunities on projects: time for a fundamental shift }\end{array}$ & $\begin{array}{l}\text { Perubahan hukum dan } \\
\text { peraturan oleh pemerintah }\end{array}$ & Politik \\
\cline { 2 - 3 } & $\begin{array}{l}\text { Loosemore, Raftery, Reilly, Higgon, (2006). Risk } \\
\text { Management in Projects, Taylor \& Francis, London. }\end{array}$ & \\
\hline
\end{tabular}


(Lanjutan) Tabel 1 Identifikasi awal faktor-faktor eksternal yang berpengaruh terhadap biaya overhead

\begin{tabular}{|c|c|c|c|}
\hline & Referensi & Indikator & Dimensi \\
\hline \multirow{2}{*}{2} & $\begin{array}{l}\text { Jaafari, Ali, (2001), Management of risks, uncertainties } \\
\text { and opportunities on projects: time for a fundamental shift }\end{array}$ & \multirow{2}{*}{ Force Majeur politik } & \multirow{4}{*}{ Politik } \\
\hline & $\begin{array}{l}\text { El-Sayegh, S.M, (2008). Risk assessment and allocation } \\
\text { in the UAE construction industry. }\end{array}$ & & \\
\hline 3 & $\begin{array}{l}\text { El-Sayegh, S.M, (2008). Risk assessment and allocation } \\
\text { in the UAE construction industry. }\end{array}$ & Korupsi dan suap & \\
\hline 4 & $\begin{array}{l}\text { El-Sayegh, S.M, (2008). Risk assessment and allocation } \\
\text { in the UAE construction industry. }\end{array}$ & $\begin{array}{l}\text { keterlambatan dalam } \\
\text { persetujuan izin dan kontrak } \\
\text { dari pemerintah }\end{array}$ & \\
\hline \multirow{2}{*}{5} & $\begin{array}{l}\text { El-Sayegh, S.M, (2008). Risk assessment and allocation } \\
\text { in the UAE construction industry. }\end{array}$ & \multirow{2}{*}{$\begin{array}{l}\text { Inflasi dan perubahan harga } \\
\text { yang tiba-tiba }\end{array}$} & \multirow{5}{*}{ Ekonomi } \\
\hline & $\begin{array}{l}\text { Ehsan, Mirza, Alam, Ishaque, (2010), Risk Management in } \\
\text { construction industry, Pakistan. }\end{array}$ & & \\
\hline \multirow[b]{2}{*}{6} & $\begin{array}{l}\text { Ehsan, Mirza, Alam, Ishaque, (2010), Risk Management in } \\
\text { construction industry, Pakistan. }\end{array}$ & \multirow[b]{2}{*}{ Fluktuasi Mata Uang } & \\
\hline & $\begin{array}{l}\text { Shen, L. Y., George W. C. Wu., Catherine S. K. Ng. } \\
\text { (2001), Risk Assessment For Construction Joint Ventures } \\
\text { In China. }\end{array}$ & & \\
\hline 7 & $\begin{array}{l}\text { Shen, L. Y., George W. C. Wu., Catherine S. K. Ng. } \\
\text { (2001), Risk Assessment For Construction Joint Ventures } \\
\text { In China. }\end{array}$ & Fluktuasi suku bunga bank & \\
\hline \multirow[b]{2}{*}{8} & $\begin{array}{l}\text { Abbasi, G.Y, Abdel-Jaber, M.S, Abu-Khadejeh, A. (2005). } \\
\text { Risk Analysis for the major factors affecting the } \\
\text { construction industry in Jordan. }\end{array}$ & \multirow{2}{*}{$\begin{array}{l}\text { Pendanaan dari } \\
\text { Holding/Owner }\end{array}$} & \multirow[b]{2}{*}{ Finansial } \\
\hline & $\begin{array}{l}\text { Ujene,A.O., Idoro, G.I., and Odesola L.A. (2013). } \\
\text { Contractors Perceptions of Effects of Project Overhead } \\
\text { Costs on Building Project Performance in South-South of } \\
\text { Nigeria. }\end{array}$ & & \\
\hline \multirow[b]{2}{*}{9} & $\begin{array}{l}\text { Soeharto, Iman, (1999), Manajemen Proyek (Dari } \\
\text { Konseptual Sampai Operasional), Jakarta, Erlangga. }\end{array}$ & \multirow{2}{*}{$\begin{array}{l}\text { Timbulnya kesulitan akibat } \\
\text { dari Hak Paten }\end{array}$} & \\
\hline & $\begin{array}{l}\text { Project Management Institute, (2008), A Guide to the } \\
\text { Project Management Body Of Knowledge (PMBOK } \\
\text { Guide), Fourth Edition, USA. }\end{array}$ & & \\
\hline \multirow[b]{2}{*}{10} & $\begin{array}{l}\text { Soeharto, Iman, (1999), Manajemen Proyek (Dari } \\
\text { Konseptual Sampai Operasional), Jakarta, Erlangga. }\end{array}$ & \multirow{2}{*}{$\begin{array}{l}\text { Timbulnya Kesulitan akibat } \\
\text { dari Lisensi }\end{array}$} & \\
\hline & $\begin{array}{l}\text { Project Management Institute, (2008), A Guide to the } \\
\text { Project Management Body Of Knowledge (PMBOK } \\
\text { Guide), Fourth Edition, USA. }\end{array}$ & & \\
\hline 11 & $\begin{array}{l}\text { Soeharto, Iman, (1999), Manajemen Proyek (Dari } \\
\text { Konseptual Sampai Operasional), Jakarta, Erlangga. }\end{array}$ & $\begin{array}{l}\text { ketidakjelasan pasal-pasal di } \\
\text { dalam kontrak }\end{array}$ & Legal \\
\hline 12 & $\begin{array}{l}\text { Soeharto, Iman, (1999), Manajemen Proyek (Dari } \\
\text { Konseptual Sampai Operasional), Jakarta, Erlangga. }\end{array}$ & $\begin{array}{l}\text { Cara Pembayaran, Change } \\
\text { Order, dan klaim }\end{array}$ & \\
\hline \multirow{2}{*}{13} & $\begin{array}{l}\text { Soeharto, Iman, (1999), Manajemen Proyek (Dari } \\
\text { Konseptual Sampai Operasional), Jakarta, Erlangga. }\end{array}$ & \multirow{2}{*}{$\begin{array}{l}\text { Masalah jaminan, warranty } \\
\text { dan guarantee }\end{array}$} & \\
\hline & $\begin{array}{l}\text { El-Sayegh, S.M, (2008). Risk assessment and allocation } \\
\text { in the UAE construction industry. }\end{array}$ & & \\
\hline 14 & $\begin{array}{l}\text { Project Management Institute, (2008), A Guide to the } \\
\text { Project Management Body Of Knowledge (PMBOK } \\
\text { Guide), Fourth Edition, USA. }\end{array}$ & $\begin{array}{l}\text { Tuntutan Hukum akibat } \\
\text { pelanggaran kontrak }\end{array}$ & \\
\hline
\end{tabular}


(Lanjutan) Tabel 1 Identifikasi awal faktor-faktor eksternal yang berpengaruh terhadap biaya overhead

\begin{tabular}{|c|c|c|c|}
\hline & Referensi & Indikator & Dimensi \\
\hline 15 & $\begin{array}{l}\text { El-Sayegh, S.M, (2008). Risk assessment and allocation } \\
\text { in the UAE construction industry. }\end{array}$ & $\begin{array}{l}\text { kondisi situs yang tidak } \\
\text { terduga }\end{array}$ & \multirow{4}{*}{ Alam } \\
\hline \multirow{2}{*}{16} & $\begin{array}{l}\text { Soeharto, Iman, (1999), Manajemen Proyek (Dari } \\
\text { Konseptual Sampai Operasional), Jakarta, Erlangga. }\end{array}$ & \multirow{2}{*}{ cuaca buruk } & \\
\hline & $\begin{array}{l}\text { El-Sayegh, S.M, (2008). Risk assessment and allocation } \\
\text { in the UAE construction industry. }\end{array}$ & & \\
\hline 17 & $\begin{array}{l}\text { Ehsan, Mirza, Alam, Ishaque, (2010), Risk Management in } \\
\text { construction industry, Pakistan. }\end{array}$ & Bencana Alam & \\
\hline \multirow{2}{*}{18} & $\begin{array}{l}\text { Jaafari, Ali, (2001), Management of risks, uncertainties } \\
\text { and opportunities on projects: time for a fundamental shift }\end{array}$ & \multirow{2}{*}{$\begin{array}{l}\text { Peningkatan kewajiban akibat } \\
\text { dampak lingkungan diluar } \\
\text { batas yang di izinkan. }\end{array}$} & \multirow{2}{*}{ Lingkungan } \\
\hline & $\begin{array}{l}\text { El-Sayegh, S.M, (2008). Risk assessment and allocation } \\
\text { in the UAE construction industry. }\end{array}$ & & \\
\hline 19 & $\begin{array}{l}\text { El-Sayegh, S.M, (2008). Risk assessment and allocation } \\
\text { in the UAE construction industry. }\end{array}$ & Tindakan kriminal/pidana & \multirow{4}{*}{$\begin{array}{l}\text { Sosial \& } \\
\text { Kultural }\end{array}$} \\
\hline \multirow[b]{2}{*}{20} & $\begin{array}{l}\text { El-Sayegh, S.M, (2008). Risk assessment and allocation } \\
\text { in the UAE construction industry. }\end{array}$ & \multirow[b]{2}{*}{ ketidakadilan dalam tender } & \\
\hline & $\begin{array}{l}\text { Shen, L. Y., George W. C. Wu., Catherine S. K. Ng. } \\
\text { (2001), Risk Assessment For Construction Joint Ventures } \\
\text { In China. }\end{array}$ & & \\
\hline 21 & $\begin{array}{l}\text { El-Sayegh, S.M, (2008). Risk assessment and allocation } \\
\text { in the UAE construction industry. }\end{array}$ & $\begin{array}{l}\text { konflik akibat perbedaan } \\
\text { budaya dan tradisi di lokasi } \\
\text { proyek }\end{array}$ & \\
\hline 22 & $\begin{array}{l}\text { Santoso, K.J., Kevin.A.W, Herry.P.C., Soehendro.R.W, } \\
\text { (2021). Potret Industri Konstruksi di Surabaya Dalam } \\
\text { Masa Pandemi COVID-19. }\end{array}$ & $\begin{array}{l}\text { Peraturan protokol kesehatan } \\
\text { Pandemi COVID-19 }\end{array}$ & \multirow{2}{*}{ lainnya } \\
\hline 23 & $\begin{array}{l}\text { Alsharef, A.; Banerjee, S.; Uddin, SMJ.; Albert, A.; } \\
\text { Jaselskis, E. Early Impacts of the COVID-19 Pandemic on } \\
\text { the United States Construction Industry. }\end{array}$ & $\begin{array}{l}\text { Penundaan dan keterlambatan } \\
\text { proyek akibat pandemi } \\
\text { COVID-19 }\end{array}$ & \\
\hline
\end{tabular}

\section{METODE PENELITIAN}

\section{Metode Pengumpulan Data}

Pengumpulan data dilakukan dengan membagikan kuesioner kepada orang-orang yang bekerja di bidang konstruksi, di perusahaan kontraktor di beberapa wilayah yang ada di Indonesia. Sebelum kuesioner disebarkan, variabel-variabel pertanyaan yang ada dalam kuesioner telah melalui tahap validasi pakar yang divalidasi oleh 5 orang pakar. Tujuan dilakukannya validasi pakar adalah untuk memperkuat variabel yang ada dalam kuesioner. Dari validasi pakar diperoleh sebanyak 21 variabel yang disetujui, kemudian hanya variabel yang telah disetujui tersebut yang dipakai sebagai variabel dalam kuesioner. Adapun responden yang ditargetkan untuk mengisi kuesioner adalah project manager, project coordinator, quantity surveyor, cost control, direktur, dan owner perusahaan.

\section{Metode Analisis Data}

Metode pengolahan data yang digunakan dalam penelitian ini adalah teknik analisis faktor, yaitu untuk menentukan faktor dominan dengan cara mengidentifikasi hubungan antara sejumlah faktor independen dengan melakukan uji korelasi. Pada penelitian ini ,digunakan teknik analisis faktor karena dengan menggunakan analisis faktor dapat mereduksi hanya faktor-faktor yang dominan saja, sehingga diharapkan faktor dominan yang dihasilkan lebih applicable. Sebelum dilakukan analisis faktor maka perlu dilakukan uji validitas untuk mengetahui sesuai atau tidaknya data yang diperoleh. Pengujian validitas data dilakukan dengan menggunakan software SPSS dengan melihat angka r hasil (Pearson Correlation) melalui sub menu Correlate pada pilihan Bivariate (Pratisto, 2009). Selanjutnya, nilai $r$ hitung dari analisis SPSS dibandingkan dengan nilai $r$ tabel (Pearson Product Moment) pada taraf signifikansi 
5\%. Apabila nilai $\mathrm{r}$ hitung lebih besar dari $\mathrm{r}$ tabel 5\%, maka variabel tersebut dinyatakan valid. Kemudian data yang valid dilanjutkan uji instrumen berikutnya, yaitu uji reliabilitas yang bertujuan untuk mengetahui tingkat konsistensi dari suatu alat pengumpulan data yang digunakan. Artinya, apakah alat ukur tersebut akan mendapatkan hasil pengukuran yang konsisten jika digunakan berulang. Metode Cronbach's Alpha merupakan metode yang sering digunakan dalam pengujian reliabilitas untuk mengukur skala rentang, seperti skala likert 1-5. Selanjutnya setelah dilakukan uji validitas dan reliabilitas, data diuji normalitasnya dengan uji normalitas yang bertujuan untuk mengetahui apakah data yang digunakan terdistribusi normal atau tidak. Uji normalitas dalam penelitian ini menggunakan Saphiro-Wilk dimana data dapat dinyatakan terdistribusi normal apabila nilai signifikansi dari uji Saphiro-Wilk lebih besar dari 0,05.Setelah melalui tiga pengujian instrumen tersebut, data yang valid, reliabel, dan terdistribusi normal kemudian digunakan dalam analisis faktor. Secara umum, tahap analisis faktor adalah yang pertama menguji korelasi antara variabel asli untuk menyederhanakan penyusutan variabel. Kemudian menentukan nilai KMO (Kaiser-Meyer-Olkin) dan dilanjutkan dengan penentuan nilai Measure of Sampling Adequacy (MSA) yang merupakan kelayakan semua variabel yang diamati untuk analisis faktor. Setelah semua variabel dinyatakan memenuhi syarat untuk analisis faktor, dilanjutkan dengan ekstraksi faktor berdasarkan kriteria nilai eigenvalue untuk mendapatkan jumlah faktor yang terbentuk. Metode yang dapat digunakan dalam ekstraksi faktor meliputi Analisis Komponen Utama. Setelah didapatkan jumlah gugus faktor dominan yang terbentuk, dilakukan rotasi faktor guna mendapatkan struktur faktor yang lebih sederhana untuk memudahkan interpretasi. Tahap terakhir dari analisis faktor adalah menginterpretasikan hasil analisis faktor yang dapat dilakukan dengan mengetahui variabel-variabel yang menyusunnya. Analisis data dilakukan menggunakan program SPSS.

\section{HASIL DAN PEMBAHASAN}

\section{Validasi Pakar}

Dari hasil validasi pakar diperoleh, diperoleh sebanyak 21 variabel yang disetujui. Kemudian variabel yang disetujui tersebut digunakan sebagai variabel pernyataan daam kuesioner. Adapun jumlah pakar yang berpartisipasi dalam proses validasi pakar sebanyak 5 orang. Variabel yang disetujui setelah validasi pakar dapat dilihat pada Tabel 2 berikut.

Tabel 2 Hasil Validasi Pakar

\begin{tabular}{|c|c|c|}
\hline Kode & Indikator & Dimensi \\
\hline $\mathrm{X} 2$ & Force Majeur politik & \multirow{3}{*}{ Politik } \\
\hline X3 & Korupsi dan suap & \\
\hline $\mathrm{X} 4$ & keterlambatan dalam persetujuan izin dan kontrak dari pemerintah & \\
\hline $\mathrm{X} 5$ & Inflasi dan perubahan harga yang tiba-tiba & \multirow{3}{*}{ Ekonomi } \\
\hline X6 & Fluktuasi Mata Uang & \\
\hline $\mathrm{X} 7$ & Fluktuasi suku bunga bank & \\
\hline X8 & Pendanaan dari Holding/Owner mempengaruhi biaya overhead & Finansial \\
\hline X9 & $\begin{array}{l}\text { Timbulnya kesulitan akibat dari Hak Paten dalam desain bangunan mempengaruhi } \\
\text { biaya overhead }\end{array}$ & \multirow{5}{*}{ Legal } \\
\hline $\mathrm{X} 10$ & Timbulnya Kesulitan akibat dari Lisensi perusahaan mempengaruhi biaya overhead & \\
\hline $\mathrm{X} 11$ & ketidakjelasan pasal-pasal di dalam kontrak mempengaruhi biaya overhead & \\
\hline $\mathrm{X} 12$ & Cara Pembayaran, Change Order, dan klaim mempengaruhi biaya overhead & \\
\hline $\mathrm{X} 14$ & Tuntutan Hukum akibat pelanggaran kontrak mempengaruhi biaya overhead & \\
\hline X15 & Kondisi situs yang tidak terduga di lokasi proyek mempengaruhi biaya overhead & \multirow{3}{*}{ Alam } \\
\hline $\mathrm{X} 16$ & Cuaca buruk yang tidak terduga di lokasi proyek mempengaruhi biaya overhead & \\
\hline $\mathrm{X} 17$ & Bencana Alam mempengaruhi biaya overhead & \\
\hline $\mathrm{X} 18$ & $\begin{array}{l}\text { Peningkatan kewajiban akibat dampak lingkungan diluar batas yang di izinkan } \\
\text { mempengaruhi biaya overhead }\end{array}$ & Lingkungan \\
\hline
\end{tabular}


(Lanjutan) Tabel 2 Hasil Validasi Pakar

\begin{tabular}{|c|c|c|}
\hline Kode & Indikator & Dimensi \\
\hline $\mathrm{X} 19$ & Adanya tindakan kriminal/pidana mempengaruhi biaya overhead & \multirow{3}{*}{$\begin{array}{l}\text { Sosial \& } \\
\text { Budaya }\end{array}$} \\
\hline $\mathrm{X} 20$ & $\begin{array}{l}\text { Persaingan yang tidak sehat / ketidakadilan dalam tender mempengaruhi biaya } \\
\text { overhead }\end{array}$ & \\
\hline $\mathrm{X} 21$ & $\begin{array}{l}\text { Adanya konflik akibat perbedaan budaya dan tradisi di lokasi proyek } \\
\text { mempengaruhi biaya overhead }\end{array}$ & \\
\hline X22 & $\begin{array}{l}\text { Adanya protokol kesehatan yang ketat selama masa pandemi COVID-19 } \\
\text { mempengaruhi biaya overhead }\end{array}$ & \multirow{2}{*}{ Lainnya } \\
\hline $\mathrm{X} 23$ & $\begin{array}{l}\text { Penurunan tingkat produktivitas yang di sebabkan oleh pembatasan jumlah tenaga } \\
\text { kerja (pembatasan sosial) selama masa pandemi COVID-19 mempengaruhi biaya } \\
\text { overhead }\end{array}$ & \\
\hline
\end{tabular}

\section{Data Kuesioner}

Selanjutnya setelah melalui validasi pakar, kuesioner disebarkan kepada 34 responden yang merupakan pelaku proyek dari pihak kontraktor proyek. Dalam penelitian ini, peneliti berhasil mengumpulkan data sebanyak 30 responden. Adapun karakterisrik posisi/jabatan dari responden di proyek di tunjukkan pada Tabel 3 berikut.

Tabel 3 karakteristik responden berdasarkan posisi atau jabatan di proyek

\begin{tabular}{cc}
\hline Posisi/Jabatan & Jumlah Responden \\
\hline Project Manager & 8 \\
Project Coordinator & 1 \\
Quantity Surveyor & 16 \\
Cost Control & 1 \\
Direktur & 1 \\
Owner Perusahaan & 2 \\
Konsultan & 1 \\
\hline TOTAL & $\mathbf{3 0}$ \\
\hline
\end{tabular}

Tabulasi data hasil pengumpulan kuesioner dapat dilihat pada Tabel 4 dibawah ini

Tabel 4 Tabulasi Data Hasil Kuesioner

\begin{tabular}{|c|c|c|c|c|c|c|}
\hline \multirow{2}{*}{ Kode } & \multirow{2}{*}{ Faktor Eksernal } & \multicolumn{5}{|c|}{ Skala } \\
\hline & & 1 & 2 & 3 & 4 & 5 \\
\hline $\mathrm{X} 2$ & $\begin{array}{l}\text { Terjadinya force majeure politik seperti kerusuhan, pemogokan, kerusuhan sipil, } \\
\text { perang, invasi, terorisme \& kekacauan agama mempengaruhi biaya overhead }\end{array}$ & 0 & 3 & 3 & 13 & 11 \\
\hline X3 & $\begin{array}{l}\text { korupsi dan suap di unit pengawas proyek konstruksi mempengaruhi biaya } \\
\text { overhead }\end{array}$ & 1 & 2 & 5 & 10 & 12 \\
\hline $\mathrm{X} 4$ & $\begin{array}{l}\text { keterlambatan dalam proses persetujuan izin dan kontrak dari pemerintah } \\
\text { mempengaruhi biaya overhead }\end{array}$ & 1 & 2 & 4 & 16 & 7 \\
\hline X5 & $\begin{array}{l}\text { Terjadinya Inflasi dan perubahan harga yang tiba-tiba selama fase konstruksi } \\
\text { mempengaruhi biaya overhead }\end{array}$ & 0 & 4 & 3 & 15 & 8 \\
\hline X6 & $\begin{array}{l}\text { ketersediaan dan fluktuasi pertukaran mata uang asing mempengaruhi biaya } \\
\text { overhead }\end{array}$ & 0 & 6 & 9 & 13 & 2 \\
\hline $\mathrm{X} 7$ & Terjadinya fluktuasi suku bunga bank mempengaruhi biaya overhead & 0 & 6 & 8 & 12 & 4 \\
\hline X8 & Pendanaan dari Holding/Owner mempengaruhi biaya overhead & 0 & 4 & 8 & 14 & 4 \\
\hline
\end{tabular}


(Lanjutan) Tabel 4 Tabulasi Data Hasil Kuesioner

\begin{tabular}{|c|c|c|c|c|c|c|}
\hline \multirow{2}{*}{ Kode } & \multirow{2}{*}{ Faktor Eksernal } & \multicolumn{5}{|c|}{ Skala } \\
\hline & & 1 & 2 & 3 & 4 & 5 \\
\hline X9 & $\begin{array}{l}\text { Timbulnya kesulitan akibat dari Hak Paten dalam desain bangunan } \\
\text { mempengaruhi biaya overhead }\end{array}$ & 1 & 7 & 11 & 10 & 1 \\
\hline X10 & $\begin{array}{l}\text { Timbulnya Kesulitan akibat dari Lisensi perusahaan mempengaruhi biaya } \\
\text { overhead }\end{array}$ & 1 & 8 & 9 & 12 & 0 \\
\hline $\mathrm{X} 11$ & ketidakjelasan pasal-pasal di dalam kontrak mempengaruhi biaya overhead & 0 & 6 & 8 & 12 & 4 \\
\hline $\mathrm{X} 12$ & Cara Pembayaran, Change Order, dan klaim mempengaruhi biaya overhead & 0 & 2 & 8 & 10 & 10 \\
\hline $\mathrm{X} 14$ & Tuntutan Hukum akibat pelanggaran kontrak mempengaruhi biaya overhead & 0 & 2 & 7 & 18 & 3 \\
\hline $\mathrm{X} 15$ & Kondisi situs yang tidak terduga di lokasi proyek mempengaruhi biaya overhead & 0 & 2 & 3 & 17 & 8 \\
\hline $\mathrm{X} 16$ & Cuaca buruk yang tidak terduga di lokasi proyek mempengaruhi biaya overhead & 0 & 1 & 4 & 15 & 10 \\
\hline $\mathrm{X} 17$ & Bencana Alam mempengaruhi biaya overhead & 0 & 1 & 1 & 13 & 15 \\
\hline X18 & $\begin{array}{l}\text { Peningkatan kewajiban akibat dampak lingkungan diluar batas yang diizinkan } \\
\text { mempengaruhi biaya overhead }\end{array}$ & 0 & 2 & 4 & 17 & 7 \\
\hline X19 & Adanya tindakan kriminal/pidana mempengaruhi biaya overhead & 3 & 1 & 3 & 20 & 3 \\
\hline $\mathrm{X} 20$ & $\begin{array}{l}\text { Persaingan yang tidak sehat / ketidakadilan dalam tender mempengaruhi biaya } \\
\text { overhead }\end{array}$ & 3 & 2 & 7 & 13 & 5 \\
\hline X21 & $\begin{array}{l}\text { Adanya konflik akibat perbedaan budaya dan tradisi di lokasi proyek } \\
\text { mempengaruhi biaya overhead }\end{array}$ & 2 & 6 & 9 & 12 & 1 \\
\hline $\mathrm{X} 22$ & $\begin{array}{l}\text { Adanya protokol kesehatan yang ketat selama masa pandemi COVID-19 } \\
\text { mempengaruhi biaya overhead }\end{array}$ & 0 & 2 & 4 & 16 & 8 \\
\hline X23 & $\begin{array}{l}\text { Penurunan tingkat produktivitas yang disebabkan oleh pembatasan jam kerja } \\
\text { selama masa pandemi COVID-19 mempengaruhi biaya overhead }\end{array}$ & 2 & 4 & 7 & 10 & 7 \\
\hline
\end{tabular}

\section{Uji Validitas, Uji Reliabilitas, dan Uji Normalitas}

Pada penelitian ini, pengujian validitas dilakukan dengan metode bivariate. Suatu variabel dapat dinyatakan valid apabila nilai $\mathrm{r}$ hitung (pearson correlation) pada suatu variabel lebih besar dari pada nilai $\mathrm{r}$ tabel (product moment). Pada penelitian ini, diperoleh data sampel sebanyak $30(\mathrm{~N}=30)$ dengan menggunakan taraf signifikansi yang dipakai adalah sebesar 5\%, dimana nilai r product moment pada tabel adalah 0,3610. Kemudian nilai $r$ hitung yang diperoleh dari SPSS dibandingkan dengan nilai $\mathrm{r}$ tabel. Hasil uji validitas dapat dilihat pada Tabel 5 berikut.

Tabel 5 Hasil Uji Validitas

\begin{tabular}{cccc}
\hline Variabel & Pearson Correlation & R tabel & Keterangan \\
\hline X3 & 0,552 & 0,361 & VALID \\
X4 & 0,486 & 0,361 & VALID \\
X5 & 0,407 & 0,361 & VALID \\
X6 & 0,443 & 0,361 & VALID \\
X7 & 0,627 & 0,361 & VALID \\
X10 & 0,477 & 0,361 & VALID \\
X11 & 0,5 & 0,361 & VALID \\
X14 & 0,51 & 0,361 & VALID \\
\hline
\end{tabular}


(Lanjutan) Tabel 5 Hasil Uji Validitas

\begin{tabular}{cccc}
\hline Variabel & Pearson Correlation & R tabel & Keterangan \\
\hline X15 & 0,501 & 0,361 & VALID \\
X16 & 0,505 & 0,361 & VALID \\
X18 & 0,462 & 0,361 & VALID \\
X20 & 0,6 & 0,361 & VALID \\
X21 & 0,612 & 0,361 & VALID \\
X23 & 0,533 & 0,361 & VALID \\
\hline
\end{tabular}

Variabel-variabel yang tidak valid dihilangkan dari proses analisis. Pada tabel 4.5 memperlihatkan variabel-variabel yang valid berdasarkan uji validitas yang dilakukan sebanyak tiga kali. Selanjutnya, dilakukan uji reliabilitas terhadap 14 variabel yang valid tersebut untuk mengetahui reliabel atau tidaknya suatu instrumen penelitian. Uji validitas dilakukan dengan menghitung nilai koefisien Cronbach Alpha. Dari hasil analisis, didapat nilai Cronbach Alpha sebesar 0,791, yang berarti instrumen penelitian tersebut dapat dikatakan reliabel $(>0,6)$. selanjutnya, setelah dilakukan uji reliabilitas, dilakukan uji normalitas dan diperoleh nilai signifikansi Shapiro-Wilk sebesar 0,184, sehingga data dapat dikatakan berdistribusi normal $(>0,05)$.

\section{Analisis Faktor}

Setelah variabel valid, reliabel, dan terdistribusi normal; selanjutnya dilakukan analisis faktor terhadap 14 variabel tersebut. Hasil analisis faktor yang ditampilkan adalah hasil yang tidak memenuhi asumsi dan siklus akhir dari analisis faktor. Pada uji MSA terhadap 14 variabel, didapatkan bahwa nilai Anti-Image Correlation variabel X3, X4, X6, X15, X16, X18 adalah kurang dari 0,5 $(<0,5)$. Hasil uji MSA ditunjukkan pada Tabel 6 berikut ini.

Tabel 6 Hasil Uji MSA

\begin{tabular}{cc}
\hline Variabel & Anti-image Correlation \\
\hline X3 & 0,428 \\
X4 & 0,45 \\
X5 & 0,512 \\
X6 & 0,48 \\
X7 & 0,643 \\
X10 & 0,583 \\
X11 & 0,515 \\
X14 & 0,527 \\
X15 & 0,473 \\
X16 & 0,477 \\
X18 & 0,457 \\
X20 & 0,565 \\
X21 & 0,593 \\
X23 & 0,639 \\
\hline
\end{tabular}

Maka selanjutnya dilakukan pengujian analisis faktor dengan menghilangkan variabel X3, X4, X6, X15, X16, dan X18. Pada penelitian ini, uji MSA dilakukan sebanyak 3 (tiga) kali. Pada pengujian MSA ketiga kalinya, barulah didapatkan seluruh nilai Anti-image Correlation pada 7 variabel di atas 0,5, maka analisis faktor dapat dilanjutkan. Tahap yang selanjutnya dalam analisis faktor adalah ekstraksi faktor. Pada tahap ini, yang dilakukan adalah dengan melihat nilai diperoleh nilai extraction pada tabel communalities. Pada penelitian ini, nilai extraction dari 7 variabel lebih besar dari 0,5. Maka, dapat disimpulkan bahwa semua variabel yang diteliti dapat dipakai menjelaskan ketujuh faktor. Berdasarkan grafik scree plot yang diperoleh dari hasil analisis menggunakan SPSS, hasil initial eigenvalue 
menunjukkan bahwa ada 3 kelompok daktor dominan yang akan terbentuk, yaitu kelompok faktor 1, 2, dan 3. Nilai eigenvalue setiap komponen ditunjukkan pada Gambar 1 di bawah ini.

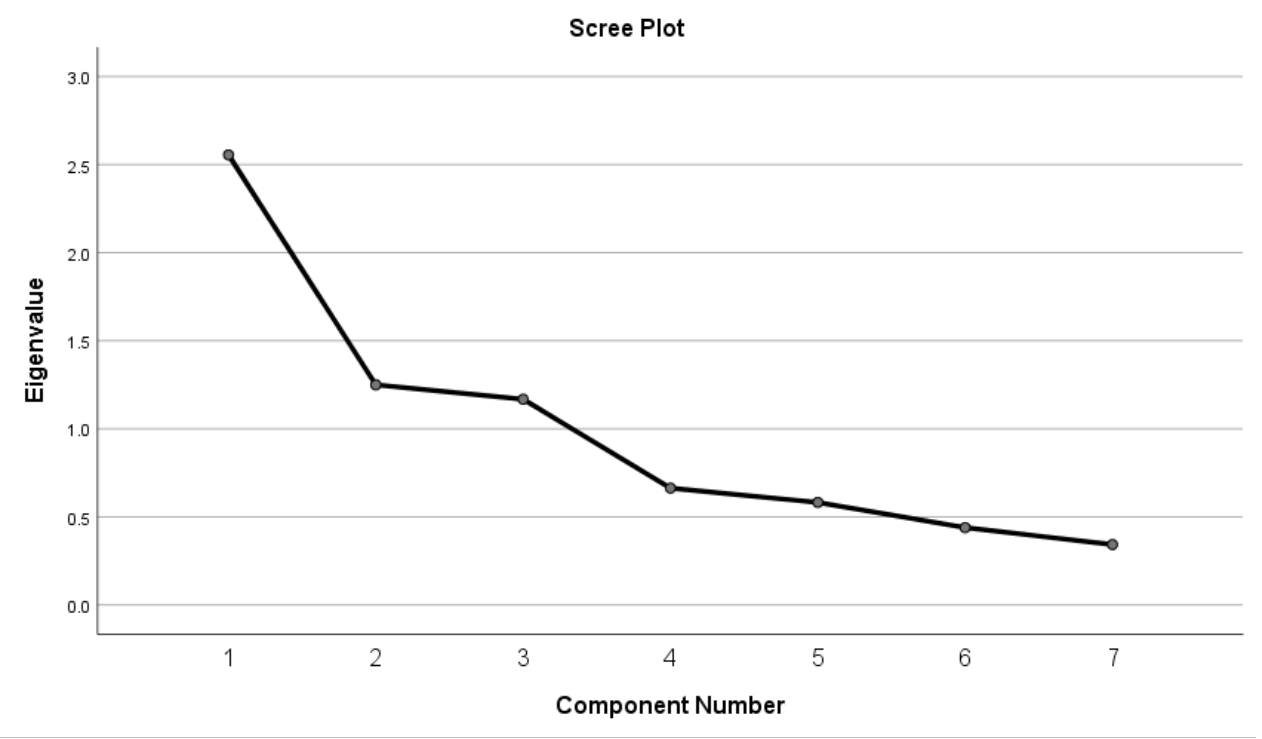

Gambar 1 Scree Plot

Pada faktor 1, besar variansi yang dapat dijelaskan adalah sebesar 36,501\%, faktor 2 sebesar 17,855\%, dan faktor 3 sebesar 16,682\%. Maka total dari ketiga kelompok faktor tersebut mampu menjelaskan variabel sebesar 71,038\%. Setelah mengetahui jumlah faktor dominan yang bisa terbentuk, maka langkah selanjutnya adalah rotasi faktor, yaitu menentukan masing-masing faktor dominan yang akan masuk ke dalam kelompok faktor 1, faktor 2, atau faktor 3 dengan cara melihat tabel rotated component matrix yang ditunjukkan pada Tabel 7 berikut.

Tabel 7 Rotated Component Matrix

\begin{tabular}{lrcc}
\hline \multicolumn{4}{c}{ Rotated Component Matrix } \\
\multicolumn{4}{c}{ Component } \\
& 1 & 2 & 3 \\
\hline X5 & 0,867 & $-0,056$ & 0,072 \\
X7 & 0,782 & 0,382 & 0,110 \\
X10 & 0,372 & 0,784 & $-0,078$ \\
X11 & $-0,013$ & 0,832 & 0,174 \\
X20 & 0,445 & 0,206 & 0,572 \\
X21 & $-0,122$ & 0,399 & 0,720 \\
X23 & 0,145 & $-0,195$ & 0,801 \\
\hline
\end{tabular}

Dalam menentukan variabel yang masuk ke kelompok faktor tertentu didasarkan pada besarnya nilai korelasi antara variabel dengan setiap kelompok faktor yang terbentuk, yaitu variabel yang memiliki nilai korelasi terhadap kelompok faktor yang paling besar. Dengan demikian, maka dapat disimpulkan kelompok faktor beserta faktor-faktor dominan yang membentuknya, yakni: kelompok faktor 1 terdiri atas faktor-faktor dominan X5, X7; Kelompok faktor 2 terdiri atas faktor-faktor dominan X10, X11; Kelompok faktor 3 terdiri atas faktor-faktor dominan X20, X21, X23.

\section{Hasil Tambahan}

Pada penelitian ini, peneliti juga melakukan survei mengenai kisaran berapa persen besaran biaya overhead yang disisihkan dari biaya langsung proyek konstruksi untuk mengantisipasi kerugian yang disebabkan oleh biaya overhead. Hasil penelitian tersebut ditunjukkan dalam Tabel 8 berikut. 
Tabel 8 Besaran persentase biaya overhead

\begin{tabular}{cc}
\hline Persentase Biaya Overhead & Jumlah Responden \\
\hline $1 \%-5 \%$ & 8 \\
$6 \%-10 \%$ & 14 \\
$11 \%-15 \%$ & 4 \\
$16 \%-20 \%$ & 4 \\
\hline TOTAL & $\mathbf{3 0}$
\end{tabular}

Berdasarkan hasil penelitian, sebagian besar responden menjawab biaya overhead proyek konstruksi umumnya adalah berkisar 6\%-10\% dari biaya langsung proyek konstruksi. Namun berdasarkan hasil wawancara dengan para pakar dan responden, biaya overhead proyek konstruksi juga di pengaruhi oleh pihak owner dari proyek tersebut. Untuk proyek dari pemerintah, biasanya memiliki persentase biaya overhead yang lebih tinggi di banding dengan proyek milik swasta.

Mengenai pendapat responden mengenai biaya overhead, seluruh responden setuju bahwa biaya overhead merupakan biaya yang penting, tidak boleh di abaikan, dan butuh perencanaan/perhitungan yang baik untuk memperkirakan biaya overhead.

\section{KESIMPULAN DAN SARAN}

\section{Kesimpulan}

Kelompok faktor eksternal dominan yang berpengaruh terhadap biaya overhead yang pertama adalah faktor ekonomi yang terdiri dari terjadinya inflasi dan perubahan harga yang tiba-tiba selama fase konstruksi, terjadinya fluktuasi suku bunga bank. Kelompok yang kedua adalah faktor legal yang berupa timbulnya kesulitan akibat dari lisensi perusahaan, dan ketidakjelasan pasal-pasal didalam kontrak. Kemudian kelompok faktor yang ketiga adalah faktor sosial-budaya yang berkenaan dengan adanya pandemi COVID-19 yang terdiri dari adanya persaingan yang tidak sehat/ketidakadilan dalam tender, adanya konflik akibat perbedaan budaya dan tradisi di lokasi proyek mempengaruhi biaya overhead, serta penurunan tingkat produktivitas yang disebabkan oleh pengurangan jumlah tenaga kerja karena pembatasan sosial selama masa pandemi COVID-19.

Mengenai persentase besaran biaya overhead, sebagian besar responden berpendapat bahwa persentase biaya overhead adalah sekitar 6\%-10\%. Namun pihak owner dari proyek konstruksi juga mempengaruhi persentase dari biaya overhead. Biasanya pada proyek swasta, pihak kontraktor akan menekan biaya overhead sekecil-kecilnya untuk memenangkan persaingan dalam tender. Walaupun biaya overhead memegang peranan penting dalam persaingan tender, namun biaya overhead perlu dihitung dan dan direncanakan dengan baik agar tidak terjadi pembengkakan biaya yang dapat mengakibatkan kerugian pada perusahaan. biaya overhead merupakan biaya yang perlu perencanaan dan perhitungan yang baik, dan para responden setuju bahwa kurangnya perhatian pada biaya overhead dapat menyebabkan kerugian terhadap perusahaan.

\section{Saran}

Penelitian ini dapat dilanjutkan dengan meneliti tentang metode yang digunakan dalam mengestimasi dan menentukan besarnya biaya overhead proyek konstruksi. Selain itu, mengenai faktor eksternal yang ditinjau dapat lebih di perluas lagi ataupun diteliti masing-masing pengaruhnya terhadap kinerja mutu ataupun waktu dalam proyek konstruksi serta dapat dikembangkan dengan cara memperluas perspektif, bukan hanya dari sudut pandang kontraktor, namun dapat ditinjau juga dari sudut pandang konsultan, dan pemberi kerja (owner). 4. Penulis berharap agar penelitian ini dapat menambah wawasan bagi para pembaca dan berguna untuk membantu para kontraktor dalam mengestimasi biaya overhead proyek konstruksi.

\section{DAFTAR PUSTAKA}

Abbasi, G. Y., Abdel-Jabber, M. S., \& Abu-Khadejeh, A. (2005). Risk Analysis for The Major Factors Affecting The Construction Industry In Jordan. Emirates journal for Engineering Research.

Albert, A., Alsharef, A., Banerjee, S., Jaselskis, E., \& Uddin, S. (2021). Early Impacts of The COVID-19 Pandemic on the United States Construction Industry. Int. J. Environ. Res. Public Health 2021, 18, 1559.

Cilensek, R. (1991). Understanding Contractor Overhead Cost Engineering. AACE, 33(12), p21-31.

Ehsan, N., Mirza, E., Alam, M., \& Ishaque, A. (2010). Risk management in Construction Industry, Pakistan.

El-Sawalhi, N. I., \& El-Riyati, A. (2015). An Overhead Cost Assesment for Construction Projects at Gaza Strip. American Journal of Civil Engineering. Vol.3, No.4. 
El-Sayegh, S. M. (2008). Risk Assesment and Allocation in the UAE Construction Industry. International Journal of Project Management , 431-438.

Hesami, S., \& Lavasani, S. A. (2014). Identifying and Classifying Effective Factors Affecting Overhead Costs in Constructing Projects in Iran . International Journal of Construction Engineering and management.

Jaafari, A. (2001). Management of risks, uncertainties and opportunities on projects: time for a fundamental shift. International Journal of project Management 19, 89-101.

Kiew, P. N., Ismail, S., \& Yusof, A. M. (2013). Key Performance Indicators in Construction Quality Management System. The Second International Conference on Engineering Business Management 2013 (ICEBM 2013).

Loosemore, Raftery, Reilly, \& Higgon. (2006). Risk Management in Projects. London: Taylor \& Francis Group.

Mahendra, S. S. (2004). Manajemen Proyek. Jakarta: PT. Gramedia Pustaka Utama.

Pratisto, A. (2009). Statistik Menjadi Mudah dengan SPSS 17. Jakarta: Penerbit Elex Media Komputindo.

Project Management Institute. (2008). A Guide to The Project Management Body of knowledge (PMBOK Guide), Fourth Edition. USA.

Santoso, K. J., Wijaya, K. A., Chandra, H. P., \& Ratnawidjaja, S. (2021). Potret Industri Konstruksi di Surabaya Dalam Masa Pandemi COVID-19. Jurnal Dimensi Pratama Teknik Sipil Vol. 10, No. 1.

Shen, L. Y., Wu, G. C., \& Ng, C. K. (2001). Risk Assessment For Construction Joint Ventures In China. Journal of Construction Engineering and Management. ASCE. Vol. 127, No. 1, January/February 2001.

Soeharto, I. (1999). Manajemen Proyek (Dari Konseptual Sampai Operasional). jakarta: Erlangga.

Ujene, A. O., Idoro, G. I., \& Odesola, L. A. (2013). Contractors Perceptions of Effects of Projects Overhead Costs on Building Project Performance in South-South of Nigeria. Civil Engineering Dimension, Vol. 15, No. 2, September 2013.

Wattimury, H., Walangitan, D., \& Sibi, M. (2015). Identifikasi Faktor-Faktor Cost Overrun Biaya Overhead Pada Proyek Pembangunan Manado Town Square. Jurnal Sipil Statik Vol.3 No.4 April 2015, 260-267. 
Analisis Faktor Eksternal yang Dominan terhadap Biaya Overhead Proyek Konstruksi

Hendi Wijaya, et al 